\title{
FORMULATIONS OF PLANT OILS USED IN CROP PROTECTION IN SELECTED EU MEMBER STATES
}

\author{
Magdalena SZULC, Joanna SOBCZAK \\ Institute of Plant Protection - National Research Institute, Poznań, POLAND \\ E-mail of corresponding author: $\underline{\text { M.Szulc@iorpib.poznan.pl }}$
}

Keywords: crop protection, European Union, formulations, plant oils

\begin{abstract}
An overview of lists of plant protection products used in organic farming in the European Union was carried out in 2017. For the analysis, the lists of products approved for organic farming protection from 8 European Union Member States were used: Belgium, Czech Republic, France, Germany, Hungary, Italy, Luxemburg and Slovakia.

It was found that in all the analysed Member States 10 different plant oils were recommended for use in organic farming. Nine of 10 were placed on the market as the only active substance of the plant protection products, in addition to 4 cases where plant oils were registered in the mixtures. There were very significant differences among the Member States as to availability of plant oils, as 6 out of 10 are registered in 1 country only. The plant oils registered in more than one Member State were rapeseed oil, mint oil, orange oil and fennel oil. Plant oils were registered for use in 7 different formulations. Emulsifiable concentrate was definitely the most popular among the formulations.
\end{abstract}

\section{INTRODUCTION}

Integrated pest management (IPM) - obligatory in all European Union member states from the beginning of 2014 - emphasises the growth of a healthy crop with the least possible disruption to agro-ecosystems. Following implementation of integrated pest management, alternative approaches or techniques, such as non-chemical alternatives to pesticides, should be promoted in agriculture. Therefore the study results regarding microbial products used in agriculture rise particular interest (Matyjaszczyk 2015a, Lamichhane et al. 2017). Biostimulants (Kocira et al. 2015, Kocira et al. 2017, Miziniak and Matysiak 2016) and preventive measures of pest control are also used in integrated pest management (Bocianowski et al. 2016, Walczak, Tratwal and Bocianowski 2015, Matyjaszczyk 2011, Matyjaszczyk 2015b, Jankowski et al. 2016).

Plant oils can be an interesting alternative to chemical active substances, as some of them have proven activity against crop pests (Bakkali et al. 2008; Isman 2000; Batish et al. 2008; Souguir at el. 2013). Plant protection products containing plant oils as an active substance are already placed on the market of European Union member states and some of them are qualified for use in organic agriculture.

The aim of the study was to compare the availability and the formulations of products containing plant oils recommended for use in agriculture in selected Member States of the European Union.

\section{MATERIAL AND METHODS}

An overview of lists of products to protect organic farming in the European Union was carried out in 2017. For the analysis, the plant protection products containing plant oils approved for use in organic farming were considered. The data came from 8 European Union Member States: Belgium, Czech Republic, France, Germany, Hungary, Italy, Luxemburg and Slovakia. Material for the study came from the official websites dedicated to organic farming within the Member States. 
In the remaining Member States either there were no official lists of plant protection products designed for organic farming (Denmark, Estonia, Greece, the Netherlands, Ireland, Latvia and Romania), obtaining information about such lists was very difficult (e.g. Spain and Portugal), or the lists were available but contained no plant protection products with plant oils (Croatia, Lithuania, Poland and United Kingdom).

\section{RESULTS}

Table 1 illustrates the fact that there are very significant differences in the availability of registered products containing plant oils among the analysed Member States. The most often registered for use in organic crops protection are rapeseed oil, mint oil, orange oil and fennel oil. There are also registered formulations containing plant oils in mixture with another active substance. During the research, it was noted that in all analysed member states, there were together 10 different plant oils recommended for use in organic farming. In nine cases, plant oil was the only active substance of the plant protection products. Additionally, in 4 cases, plant oil was registered in the mixtures with another active substance: Pongamia pinnata oil with linseed oil, as well as rapeseed oil in mixtures with respectively azadirachtin, lecithin and pyrethrins), as presented in table 1.

Taken together the plant oils listed in table 1 were registered for use in 7 different formulations. Emulsifiable concentrate (EC) is definitely the most often used among them. The other formulations listed in table 1 are emulsions: oil in water (EW) as well as water in oil (EO), oil to be applied in undiluted form (AL), oil dispersion (OD), soluble concentrate (SL) and hot fogging concentrate (HN).

The following plant oils were placed on the market in more than one formulation: rapeseed oil (4 different formulations), mixture of rapeseed oil and pyrethirins (2 formulations) and orange oil (2 formulations).

Table 1. Plant protection products containing plant oils approved for use in organic farming and their formulations in the analyzed European Union countries.

\begin{tabular}{|l|l|l|}
\hline Plant oils in plant protection products & \multicolumn{1}{|c|}{ Country } & Formulation* \\
\hline \multirow{2}{*}{ Fennel oil } & $\begin{array}{l}\text { Czech Republic } \\
\text { Slovakia }\end{array}$ & EC \\
\hline Gillyflower oil & Italy & EC \\
\hline \multirow{5}{*}{ Mint oil } & $\begin{array}{l}\text { Belgium } \\
\text { France } \\
\text { Germanye oil } \\
\text { Italy }\end{array}$ & HN \\
\hline Pinus oil (pinole) & $\begin{array}{l}\text { Belgium } \\
\text { Slovakia }\end{array}$ & SL \\
\cline { 2 - 3 } & Germany & EW \\
\hline Pongamia pinnata oil & Slovakia & EO \\
\hline Pongamia pinnata oil, linseed oil & Czech Republic & EC \\
\hline \multirow{5}{*}{ Rapeseed oil } & Czech Republic & EO \\
& $\begin{array}{l}\text { Belgium } \\
\text { France } \\
\text { Luxemburg }\end{array}$ & AL, EC \\
\cline { 2 - 3 } & Czech Republic & EC, OD \\
\cline { 2 - 3 } & Hungary & EC \\
\hline Rapeseed oil, azadirachtin & Luxemburg & EC \\
\hline Rapeseed oil, lecithin & Czech Republic & EC \\
\hline
\end{tabular}




\begin{tabular}{|l|l|l|}
\hline Plant oils in plant protection products & \multicolumn{1}{|c|}{ Country } & Formulation* \\
\hline Rapeseed oil, pyrethrins & $\begin{array}{l}\text { Belgium } \\
\text { Czech Republic } \\
\text { Germany } \\
\text { Luxemburg }\end{array}$ & AL, EC \\
\hline Soybean oil & Czech Republic & EC \\
\hline Sunflower oil & Hungary & EC \\
\hline
\end{tabular}

*Formulation codes are explained in the text

\section{CONCLUSION}

The following plant oils (in alphabetical order) are available for the protection of organic crops in the analysed European Union countries: fennel oil, gillyflower oil, linseed oil, mint oil, orange oil, pinus oil, Pongamia pinnata oil, rapeseed oil, soybean oil and sunflower oil. However from the point of view of particular Member State, the availability is much worse, as none of them is registered in all of the eight analysed Member States and 6 out of 10 are registered in one Member State only.

The plant oils were registered for use in 7 different formulations. Emulsifiable concentrate is definitely the most often used among them. The most often registered for use in organic crops protection are rapeseed oil, mint oil, orange oil and fennel oil.

\section{LITERATURE}

Bakkali F., Averbeck S., Averbeck D., Idaomar M. (2008). Biological effects of essential oils - a review. Food and Chemical Toxicology, 46(2), 446-475.

Batish D.R., Singh H.P., Kohli R.K., Kaur S. (2008). Eucalyptus essential oil as a natural pesticide. Forest Ecology and Management, 25(6), 2166-2174.

Bocianowski J., Szulc P., Tratwal A., Nowosad K., Piesik D. (2016). The influence of potassium to mineral fertilizers on the maize health. Journal of Integrative Agriculture, 15(6), 1286-1292.

Isman M.B. (2000). Plant essential oils for pest and disease management. Crop Protection, 19, 603-608.

Jankowski K., Hulanicki P.S., Krzebietke S., Żarczyński P., Hulanicki P., Sokólski M. (2016). Yield and quality of winter oilseed rape in response to different systems of foliar fertilization. Journal of Elementology, 21(4), 1017-1027.

Kocira A., Kocira S., Świeca M., Złotek U., Jakubczyk A., Kapela K. (2017). Effect of foliar application of a nitrophenolate-based biostimulant on the yield and quality of two bean cultivars. Scientia Horticulturae, 214, 76-82.

Kocira S., Kocira A., Szmigielski M., Piecak A., Sagan A., Malaga-Toboła U. (2015). Effect of an amino acids-containing biostimulator on common bean crop. Przemysl Chemiczny, 94(10), 1732-1736.

Lamichhane J. R., Bischoff-Scaefer M., Bluemel S., Dachbrodt -Saaydeh S., Dreux L., Jansen J.P., Kiss J., Köhl J., Kudsk P., Malausa T., Messèan A., Nicot P.C., Ricci P., Thibierge J., Villeneuve F. (2017). Identifying obstacles and ranking common biological control research priorities for Europe to manage most economically important pests in arable, vegetable and perennial crops. Pest Management Science, 73(1), 14-21.

Matyjaszczyk E. (2011). Selected aspects of plant protection in Poland, five years on from EU accession. Outlook on Agriculture, 40(2), 119-123.

Matyjaszczyk E. (2015a). Products containing microorganisms as a tool in integrated pest management and the rules of their market placement in the European Union. Pest Management Science, 71 (9), 12011206.

Matyjaszczyk E. (2015b). Prevention methods for pest control and their use in Poland. Pest Management Science, 71 (4), 485-491. 
Miziniak W., Matysiak K. (2016). Two tank-mix adjuvants effect on yield and quality attributes of wheat treated with growth retardants. Ciencia Rural, 46(9), 1559-1565

Souguir S., Chaieb I., Cheikh Z.B., Laarif A. (2013). Insecticidal activities of essential oils from some cultivated aromatic plants against Spodoptera littoralis (BOISD). Journal of Plant Protection Research, 53(4), 388-391

Walczak F., Tratwal A., Bocianowski J. (2015). Effects of Changes in Precipitation and Temperature on Select Agrophage Risk in Poland, 1965-2009. Polish Journal of Environmental Studies, 24(1), 325-332 